\title{
Peripheral nerve demyelination and a leptin receptor mutation: The obese Zucker rat sciatic nerve demyelination occurs with a centripetal pattern defect
}

\author{
Jacques Gilloteaux $^{1,2 *}$, Kritika Subramanian $^{1,3}$, Nadia Solomon $^{1}$ and Charles Nicaise ${ }^{2}$ \\ ${ }^{1}$ Department of Anatomical Sciences, St George's University School of Medicine, K.B. Taylor Global Scholar's Program at Northumbria University, Newcastle \\ upon Tyne, UK \\ ${ }^{2}$ Unité de Recherche en Physiologie Moléculaire (URPhyM), Narilis, Département de Médecine, Université de Namur, Namur, Belgium \\ ${ }^{3}$ Department of Clinical and Epidemiological Virology, Rega Institute of Medical Research, Katholieke Universiteit Leuven, Leuven, Belgium
}

\begin{abstract}
Young male Zucker rats with a leptin receptor mutation are obese, have a non-insulin-dependent diabetes mellitus (NIDDM), and other endocrinopathies. Fine structure aspects of the tibial branches of the sciatic nerve of lean $(\mathrm{Fa} /$ ? $)$ and obese $(\mathrm{fa} / \mathrm{fa})$ perfused rats were compared and revealed a progressive demyelination caused by Schwann cells (SCs). There, stacked myelin layers membranes and other adhering junctions were defective in many nerve fibers of the obese rats, including of the mesaxons of the smallest fibers. Additionally, the progressive myelin alterations caused by metabolomic alterations in membrane components sorted by the SCs may also have revealed a peculiar, centripetal mode of sorting and trafficking maintenance of the peripheral nerve myelin.
\end{abstract}

\section{Introduction}

Demyelination could be acute or chronic. However, the etiology of the degenerative process related to the nourishing layer of nerve fibers, either can involve the central [CNS] [1-3] or the peripheral nervous system [PNS] [2,4-6]. It is still poorly understood, especially in the case of diabetes [7]. In textbooks, PNS neuropathies, are topics brought along with neuromuscular anomalies [8] and the defects are classified either as (a) axonal neuropathies in which insults often consist in degeneration occurring distally and secondarily to damage to the myelin or (b) as demyelinating neuropathies characterized by Schwann cell (SC) alterations in which myelin would support abnormal conduction velocities. This latter type of insidious neural defect is apparently shortsized and can appear randomly to reduce the internode myelin sheaths while maintaining the axonal content. Changes occurring in the PNS endoneurium have been seldom investigated, contrarily of what is noted for the CNS [9-11]. Recent advances also call about cooperativity between SC basal lamina components and axon revealing paracrine and juxtacrine interactions with at least one of the neuregulins $[12,13]$.

Diabetes is known since Antiquity $[7,14]$ but the enormous literature dealing with myelin [15] and diabetes defects is mainly clinical and metabolic, If it does share ultrastructural aspects there are many controversies in the structure and diagnostic progress of the nerve defects because human myelin samples are illustrated without pinpointing to any or how some myelin component(s) that is (are) implicated in defects [16-24]. Recently, in a murine model, similar questioning occurred [25]. More precision in this NIDDM defect about the causing flaw and mechanism would solve what becomes a huge public health concern where the Zucker rat has been introduced [26,27].

This short report complements previous data on PNS myelin fibers of the obese Zucker rat with NIDDM, where it is known the leptin receptor mutation is causing diabetes, in an equivalent way of human pathology [28]. Even though, this myelinopathy associates with co-existing endocrinopathies, it demonstrates the SC's metabolic maintenance and turnover of the myelin is important and one has tried to realize, through collection of micrographs, a sort of dynamic, sequential events of the damage throughout the myelin layers. More specifically, in continuity with a previous collection of data [29], this report further illustrates the smallest myelin anomalies of tiny nerve fibers along with other examples of adjacent large size damages found throughout some of the axon's walls. Astonishingly, our ultrastructural findings on demyelination damages could also claim that one may have also unravelled a peculiar centripetal mode of myelin maintenance by SCs in PNS nerves which can be added to another found in CNS, likely originating from nodal zone, that is longitudinal, alongside its membrane's extensions [30-32].

\section{Materials and methods}

The Institutional Animal Care and Use Committee of the Northeastern Ohio Universities College of Medicine (now Northeast

${ }^{*}$ Correspondence to: Jacques Gilloteaux, Department of Anatomical Sciences, St George's University School of Medicine, UNN - School of Health and Life Sciences, Drill Hall 013, Newcastle upon Tyne NE1 8ST, UK; and URPHyMNarilis, Départment de Médecine, Université de Namur, Rue de Bruxelles 61, Namur 5000,Belgium, E-mail: jgilloteaux@sgu.edu; jacques.gilloteaux@ unamur.be

Key words: leptin receptor, myelin, NIDDM, obesity, sciatic nerve, schwann cell, Zucker rat

Received: December 12, 2019; Accepted: December 16, 2019; Published: December 20, 2019 

defect

Ohio University), Rootstown, Ohio, USA have approved the procedures of animal care, anaesthesia, euthanasia, and tissue's collection of this study and concomitant ones [29,33-35]. The collection of tissues of lean and obese Zucker young male rats have been described in detail in a recent publication, with free access [29]. These obese Zucker rats seemed to be with non-insulin dependent diabetes (NIDDM) which affliction becomes the most common and is increasing rapidly in many populations.

\section{Results}

In the previous publication, comparisons were made between light microscopy (1- $\mu \mathrm{m}$ thick epoxy sections, stained in toluidine blue) to select fields of investigations, and with those in ultrastructure of the myelin covering the nerve fibers of the sciatic tibial nerve branches $[29,34]$. Here, a small nerve fibre illustrated in Figure 1A of a normal rat is compared with that of an obese, i.e. diabetic one in Figure 1B. Noting the initial zone of myelin formation of the sciatic nerve branch with a SC makes an outer mesaxon with blemishes. Not only parts of the adaxonal membrane is disorganized instead of a distinct inner mesaxon structure but defects also occurred at the level of the outer mesaxon construction. Instead, a mush of membrane fragments appeared amongst a space occupied by a wrap vacuolated of waxy deposits in the diabetic nerve fibre (Figure 1B).

In the large nerve fibers of the lean rat, typical nerve myelin displayed no blemishes and a clear inner adaxonal membrane (Figure 2A) while the defects viewed in obese Zucker NIDDM rats (Figure $2 \mathrm{~B}-\mathrm{C}$ ) not only encompassed the similar inner myelin parts but also the concentric layers of myelin membranes that showed traversed by 'funnels' initiated in the SC's Cajal zone, progressing as narrow to enlarged and intermembranous rifts of the outer to inner myelin layer, enlarging toward the adaxonal layer, thus in a centripetal diffusion pattern (Figure 2B-C). These blemishes could be caused by trans membranous defect of macromolecules involved in adherence of myelin membranes, either as extracted or missing from SC's sorting.

\section{Discussion}

Processing the obese nerve samples may either have extracted peculiar components located in the spaces between myelin layers or, more likely, these gaps filled with vacuoles and gunky sludge were already made by the NIDDM because the control and obese Zucker rat nerves were fixed a short time after perfusion fixation and processed simultaneously and in the same methodology.
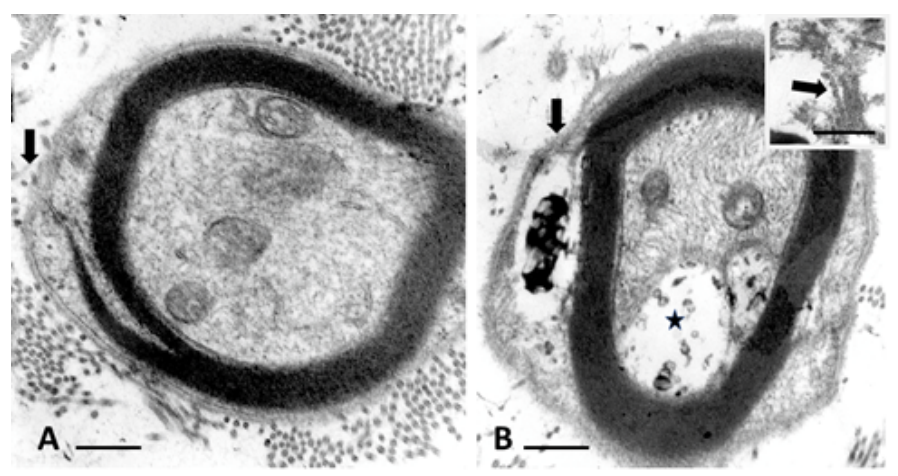

Figure 1 A-B. Small nerve fibers of lean (A) and obese (B) Zucker rat. In B: flaws in initial myelin formation of the outer mesaxon (arrows). There, the SC's Cajal band contains a space with a complex waxy deposit and the adaxonal membrane displaced develops a vacuolated space $(*)$. Both damages accompany remains of membranes as shown in insert obtained out of another section of the same nerve fibre. Scales are $500 \mathrm{~nm}$ in A and b, insert ib B is $200 \mathrm{~nm}$
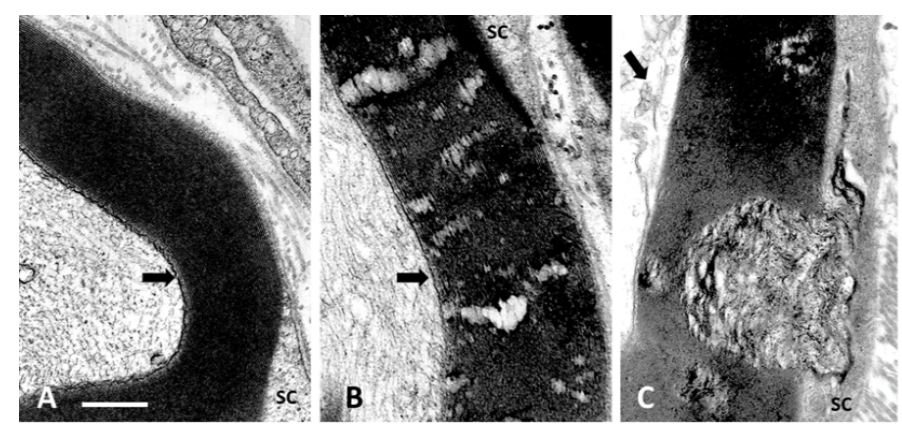

Figure 2 A-C: Parts of cross sections of large diameter myelinated nerve fibers of a lean (A) and obese (B and C) Zucker rats where the adaxonal membranes are marked by an arrow in A-C. In A: the lean rat myelin displays a regular, typical myelin wrapping. In B: channel-like damages across the myelin with C illustrating some of the complex initial wide funnel-like pockets of demyelination noted in some nerve fibers, damages appearing as wrinkled membranes initiated in the Cajal band. Scales are all equal to $500 \mathrm{~nm}$

The few micrographs exemplified here are added to the defects described in previous publications and again reveal that SCs, with their continuous maintenance of the myelin, most of the burden of metabolic changes causing this defective myelin [36-41]. The SCs are imposed complex endocrine influences through which expression and sorting of some components of the myelin can be altered [29,35]. Besides the phospholipids that seemed to organize in orderly way layers, the obese Zucker peripheral nerves showed disorders similar to those of the CNS missing a plasmalogen such as the myelin basic protein in the CNS [42]. Of course, in the PNS, such as in this case, any plasmalogen (i.e. P0 or peripheral myelin protein 22 ), ceramide, cadherin and periaxin along with connexin 32 that contribute to the architecture and adherence of the neuroplasm, could be involved [43-51]. The altered protective insulation and nerve conduction integrity could change by wrong SC expression and sorting of membrane components in the PNS [36,41,52-60] through direct or indirect endocrine influence. In these obese rat models like in some diabetic humans, leptin plethora without receptor severs the normal hypothalamo-pituitary (and pineal?) axis functions (thyroid, growth hormone, gonadotroph and corticotroph signalling defects, circadian rhythms, etc.). There, knock out mice models would provide further information as to whether some components sorting can influence the dysmyelination associated with NIDDM peripheral nerves. Out of human diabetes autopsies and other animal diabetes data, analyses of nerves from limb amputations $[61,62]$ where cholesterol-phospholipid balance have been altered [36,44,63-71]. Others have investigated the endoplasmic reticulum and other plasmalogens and glycolipids, especially P0 protein [72-78]. Thus, the observations support that in obese Zucker rat nerves, similarly to other animal models and, possibly the human, translates as well into congenital obesity [79-82]. Out of this non-inflammatory PNS demyelination, one can again bring the hypothesis that associated proteins and proteoglycans to the myelin [83], not only can turn over rafts [84-86] similarly as in CNS along the Schmidt-Lantermann incisures toward internode membranes $[31,32]$ with a sort of domino effect replacement with renewed adhesive trans membrane components sorting across an already poorly zipped membranes [73]. In our case, wrong accumulations or sorting of myelin components by SCs were also viewed as flawed by insulin disruption [60] including the tiny forming mesaxons as an initial and associated disorder in the architecture alignments of the normal wrapping without being caused by osmotic processing when compared with normal nerves $[29,87]$ and, this throughout along the changed NIDDM myelin, having components with a centripetal insertion, viewed by the evidenced growing blemishes making sorts of trans membranous 
Gilloteaux J (2019) Peripheral nerve demyelination and a leptin receptor mutation: The obese Zucker rat sciatic nerve demyelination occurs with a centripetal pattern defect

passageways across the sort of liquid crystal-like phase between myelin strata could be created by a sort of Rayleigh-Taylor instability $[88,89]$. In this case, at first, accumulated molecular species passing throughs, appear by accumulations as a processing channel-like, with centripetal orientation, widen into sectors caused by the progressively changed myelin composition.

\section{References}

1. Mokrasch LC (1969) Myelin. In Chemical Architecture of the Nervous System. Springer, Boston, MA pp:171-193

2. Dyck P, Thomas PK (2005) Peripheral Neuropathy, Vols. 1-2. Philadelphia: SaundersElsevier Inc pp: 1-2992.

3. Raine CS (1984) The neuropathology of myelin diseases. In: Morell P, ed. Myelin, 2nd. New York: Plenum Press pp. 259-310.

4. Babel J, Bischoff A, Spoedlin H (1970) Ultrastructure of the Peripheral Nervous System and Sense Organs. Atlas of Normal and Pathologic Anatomy. Bischoff A, ed. Stuttgart: Thieme Verlag 970: 100-110.

5. Hall SM (1978) The Schwann cell: a reappraisal of its role in the peripheral nervous system. Neuropathol Appl Neurobiol 4: 165-176. [Crossref]

6. Pannese E (2015) Neurocytology. Fine Structure of Neurons, Nerve Processes, and Neuroglial Cells. 2nd ed. Switzerland: Springer Verlag International pp: 1-319.

7. Thomas PK, Eliasson SG (1984) Diabetic neuropathy. In: Dyck PJ, Thomas PK, Lambert EH, Bunge R, eds. Peripheral Neuropathy, 2nd. Part F, Ch 47. Philadelphia: WB Saunders pp: 1773-1810.

8. Pytel P (2014) Peripheral nerves and muscles. In: Kumar V, Abbas AK, Aster JC (eds.), Robbins Basic Pathology. Vol. 21. 9th ed. Philadelphia: Elsevier pp: 797-809.

9. Bunge RP, Bunge MB (1978) Evidence that contact with connective tissue matrix is required for normal inter-action between Schwann cells and nerve fibers. $J$ Cell Bio 78: 943-950.

10. Yao JK, Bourre JM (1985) Metabolic alterations of endoneurial lipids in developing trembler nerve. Brain Res 325(1-2): 21-27.

11. Thomas PK, Olsson Y (1984) Microscopic anatomy and function of the connective tissue components of peripheral nerve. In: Dyck PJ, Thomas PK, Lambert EH, Bunge R, eds. Peripheral Neuropathy. 2nd ed. Philadelphia: W.B. Saunders pp: 97-120.

12. Yang D, Bierman J, Tarumi YS, Zhong YP, Rangwala R, et al. (2005) Coordinate control of axon defasciculation and myelination by laminin-2 and -8. J Cell Biol 168: 655-666. [Crossref]

13. Ghidinelli M, Poitelon Y, Shin YK, Ameroso D, Williamson C, et al. (2017) Laminin 211 inhibits protein kinase A in Schwann cells to modulate neuregulin 1 type III-driven myelination. PLoS biology 15: e2001408.

14. Medvei VC (1993) The History of Clinical Endocrinology: A Comprehensive Account of Endocrinology from Earliest Times to the Present Day. New York: The Parthenon Group Inc. pp: 1-913.

15. Boullerne AI (2016) The history of myelin. Exp Neurol 283: 431-445. [Crossref]

16. Goodman JI, Baumoel S, Frankel L, Markus LJ, Wasserman S (1953) The Diabetic Neuropathies. Springfield Ill. USA: Charles C. Thomas.

17. Tomlinson RJ, Bradley RJ, Harris RA, Jenner P (2007) Neurobiology of Diabetic Neuropathy. Academic Press-Elsevier Sciences; 2002, p 326-393.80. Said G. Diabetic neuropathy - a review. Natl Clin Pract Neurol 3: 331-340.

18. Terfaye S, Boulton A (2009) Diabetic Neuropathy. New York: Oxford University Press.

19. Salzer JL (2012) Axonal regulation of Schwann cell ensheathment and myelination. $J$ Peripher Nerv Syst 17 Suppl 3: 14-19. [Crossref]

20. Cashman CR, Höke A (2015) Mechanisms of distal axonal degeneration in peripheral neuropathies. Neurosci Lett 596: 33-50.

21. Russell JW, Zilliox LA (2014) Diabetic neuropathies. Continuum (Minneap Minn). Peripheral Nervous System Disorders 20: 1226-1240.

22. Zilliox LA, Ruby SK, Singh S, Zhan M, Russell JW (2015) Clinical neuropathy scales in neuropathy associated with impaired glucose tolerance. J Diabetes Complications 29: 372-377.
23. Fernyhough P, Calcutt NA (2016) An introduction to the history and controversies of diabetic neuropathy. Int Rev Neurobiol 1827: 115-120.

24. Fernyhough P, Calcutt NA (2016) New directions in diabetic neuropathy: evolution or extinction? Int Rev Neurobiol 127: 229-234.

25. Hackett AR, Strickland A, Milbrandt J (2019) Disrupting insulin signalling in Schwann cells impairs myelination and induces a sensory neuropathy. Glia.

26. Artinano A, Castro M (2008) Zucker rats as an experimental model for the study of various diseases. Endocrinol Nutr 55: 217-222.

27. Arnessou M, Tahiri K, Chauvet G, Desbuquois B (2010) Experimental rat models to study the metabolic syndrome. Diabetes Metab 36: 120-128.

28. Zucker LM (1965) Hereditary obesity in the rat associated with hyperlipemia. Ann N Y Acad Sci 131: 447-458. [Crossref]

29. Gilloteaux J, Subramamian K, Solomon N, Nicaise C (2018) The leptin receptor mutation of the obese Zucker rat causes sciatic nerve demyelination with a centripetal pattern defect, Ultrastruct Pathol 42: 377-408.

30. Bakhti M, Aggarwal S, Simons M (2014) Myelin architecture: zippering membranes tightly together. Cell Mol Life Sci 71: 1265-1277.

31. Snaidero N, Möbius W, Czopka T, Hekking LH, Mathisen C, et al. (2014) Myelin membrane wrapping of CNS axons by PI $(3,4,5) \mathrm{P} 3$-dependent polarized growth at the inner tongue. Cell 156: 277-290.

32. Snaidero N, Velte C, Myllykoski M, Raasakka A, Ignatev A, et al. (2017) Antagonistic functions of MBP and CNP establish cytosolic channels in CNS myelin. Cell Report 18: 314-323.

33. Gilloteaux J, Finkelstein J (1985) Peripheral neuropathies in the obese Zucker rat skeletal muscles. Anat Rec 211: 69A.

34. Gilloteaux J, Pardhan D (2015) Crinophagy in thyroid follicular and parafollicular cells of male obese Zucker rat. Ultrastruct Pathol 39: 255-269.

35. Gilloteaux J, Subramanian K, Solomon N (2017) Peripheral neuropathy and leptin receptor defect: demyelination of the sciatic nerve of the obese Zucker rat. Ultrastruct Pathol 41: 90-92.

36. Spritz N, Singh H, Marinan B (1975) Decrease in myelin content of rabbit sciatic nerve with aging and diabetes. Diabetes 24: 680-683. [Crossref]

37. Spritz N, Singh H, Marinan B, Silberlicht I (1981) Effect of experimental diabetes on the susceptibility of myelin proteins to proteolysis. Diabetes 30: 292-295.

38. Clements RS Jr (1979) Diabetic neuropathy--new concepts of its etiology. Diabetes 28: 604-611. [Crossref]

39. Hirano A (1983) Reaction of the periaxonal space to some pathologic processes. In Harry M Zimmerman ed. Progress in Neuropathology, Vol. 5. New York: Raven Press pp: 99-112.

40. Khedr E, Toony L, Tarkhan M, Abdella G (2000) Peripheral and central nervous system alterations in hypothyroidism: electrophysiological findings. Neuropsychobiology 41 $88-94$.

41. Thomas PK (2003) The Pathology of Diabetic Neuropathy. New York: J Wiley \& Sons.

42. Weil MT, Möbius W, Winkler A, Ruhwedel T, Wrzos C, et al. (2016) Loss of myelin basic protein function triggers myelin breakdown in models of demyelinating diseases. Cell Rep 16: 314-322.

43. Brunden KR, Brown DT (1990) P0 mRNA expression in cultures of Schwann cells and neurons that lack basal lamina and myelin. J Neurosci Res 27: 159-168. [Crossref]

44. Mitchell LS, Griffiths IR, Morrison S, Barrie JA, Kirkham D, et al. (1990) Expression of myelin protein gene transcripts by Schwann cells of regenerating nerve. J Neurosci Res 27: 125-135.

45. Fernandez-Valle C, Fregien N, Wood PM, Bunge MB (1993) Expression of the protein zero myelin gene in axon related Schwann cells is linked to basal lamina formation. Development 119: 867-880.

46. Kuhn G, Lie A, Wilms S, Müller HW (1993) Coexpression of PMP22 gene with MBP and P0 during de novo myelination and nerve repair. Glia 8: 256-264. [Crossref]

47. Naef R, Suter U (1998) Many facets of the peripheral myelin protein PMP22 in myelination and disease. Microsc Res Tech 41: 359-371. [Crossref]

48. Spiryda LB (1998) Myelin protein zero and membrane adhesion. J Neurosci Res 54 137-146. [Crossref] 

defect

49. D’Urso D, Ehrhardt P, Müller HW (1999) Peripheral myelin protein 22 and protein zero: a novel association in peripheral nervous system myelin. J Neurosci 19: 33963403 .

50. Xu W, Manichella D, Jiang H, Vallat JM, Lilien J, et al. (2000) Absence of P0 leads to the dysregulation of myelin gene expression and myelin morphogenesis. J Neurosci Res 60: 714-724. [Crossref]

51. Hassea B, Bossea F, Hanenberg H, Müller HW (2004) Peripheral myelin protein 22 kDa and protein zero: domain specific trans-interactions. Mol Cell Neurosci 27: 370-378.

52. Figlewicz DA, Quarles RH, Johnson D, Barbarash GR, Sternberger NH (1981) Biochemical demonstration of the myelin-associated glycoprotein in the peripheral nervous system. $J$ Neurochem 37: 749-758.

53. Trapp BD, Quarles RH (1982) Presence of the myelin-associated glycoprotein correlates with alterations in the periodicity of peripheral myelin. J Cell Biol 92: 877-882.

54. Boiron F, Spivack WD, Deshmukh DS, Gould RM (1993) Basis for phospholipid incorporation into peripheral nerve myelin. J Neurochem 60: 320-329.

55. Carenini S, Montag D, Cremer H, Schachner M, Martini R (1997) Absence of the myelin-associated glycoprotein (MAG) and the neural cell adhesion molecule (NCAM) interferes with the maintenance, but not with the formation of peripheral myelin. Cell Tissue Res 287: 3-9.

56. Brown DA, London E (2000) Structure and function of sphingolipid- and cholesterolrich membrane rafts. J Biol Chem 275: 17221-17224. [Crossref]

57. Menichella DM, Arroyo EJ, Awatramani R, Xu T, Baron P, et al. (2001) Protein zero is necessary for E-cadherin-mediated adherens junction formation in Schwann cells. Mol Cell Neurosci 18: 606-618.

58. Quarles RH (2002) Myelin sheaths: glycoproteins involved in their formation, maintenance and degeneration. Cell Mol Life Sci 59: 1851-1871.

59. Jahn O, Tenzer S, Werner HB (2009) Myelin proteomics: molecular anatomy of an insulating sheath. Mol Neurobiol 40: 55-72.

60. Rachana KS, Manu MS, Advirao GM (2016) Insulin influenced expression of myelin proteins in diabetic peripheral neuropathy. Neurosci Lett 629: 110-115.

61. Jordan WR, Randall LO (1936) Neuropathy in diabetes: lipid constituents of nerves. $J$ Nerv Ment Dis 84: 583.

62. Margolis RU, Margolis RK (1977) Metabolism and function of glycoproteins and glycosaminoglycans in nervous tissue. Int J Biochem 8: 85-91.

63. van Dijck PW (1979) Negatively charged phospholipids and their position in the cholesterol affinity sequence. Biochim Biophys Acta 555: 89-101.

64. Brown MJ, Sumner AJ, Greene DA, Diamond SM, Asbury AK (1980) Distal neuropathy in experimental diabetes mellitus. Ann Neurol 8:168-178.

65. Gould RM, Holshek J, Silverman W, Spivack WD (1987) Localization of phospholipid synthesis to Schwann cells and axons. J Neurochem 48: 1121-1131. [Crossref]

66. Gould RM, Connell F, Spivack W (1987) Phospholipid metabolism in mouse sciatic nerve in vivo. $J$ Neurochem 48: 853-859.

67. Driscoll D, Ennis W, Meneses P (1994) Human sciatic nerve phospholipid profiles from non-diabetes mellitus, noninsulin-dependent diabetes mellitus and insulin-dependent diabetes mellitus individuals. A 31P NMR spectroscopy study. Int J Biochem 26: 759-767.

68. Eckhardt M (2008) The role and metabolism of sulfatide in the nervous system. Mol Neurobiol 37: 93-103. [Crossref]

69. Patzig J, Jahn O, Tenzer S, Werner HB (2011) Quantitative and integrative proteome analysis of peripheral nerve myelin identifies novel myelin proteins and candidate neuropathy loci. J Neurosci 31: 16369-16386.
70. Viader A, Sasaki Y, Kim S, Strickland A, Workman CS, et al. (2013) Aberrant Schwann cell lipid metabolism linked to mitochondrial deficits leads to axon degeneration and neuropathy. Neuron 77: 886-898.

71. Tsutsui S, Stys PK (2013) Metabolic injury to axons and myelin. Exp Neurol 246 26-34. [Crossref]

72. Pop-Busui R, Sima A, Stevens M (2006) diabetic neuropathy and oxidative stress. Diabetes Metab Res Rev 22: 257-273.

73. Hoshi T, Suzuki A, Hayashi S, Tohyama K, Hayashi A, et al. (2007) Nodal protrusions, increased Schmidt-Lantermann incisures, and paranodal disorganization are characteristic features of sulfatide-deficient peripheral nerves. Glia 55: 584-594.

74. Lupachyk S, Watcho P, Obrosov AA, Stavnichuk R, Obrosova IG (2013) Endoplasmic reticulum stress contributes to prediabetic peripheral neuropathy. Exp Neurol 247: 342348

75. Wang Y, Wong RH, Tang T, Hudak CS, Yang D, et al. (2013) Phosphorylation and recruitment of BAF60c in chromatin remodeling for lipogenesis in response to insulin. Mol Cell 49: 283-297. [Crossref]

76. Farese RV, Lee MC, Sajan MP (2014) Atypical PKC: a target for treating insulinresistant disorders of obesity, the metabolic syndrome and type 2 diabetes mellitus. Expert Opin Ther Targets 18: 1163-1175.

77. Ino D, Iino M (2017) Schwann cell mitochondria as key regulators in the developmen and maintenance of peripheral nerve axons. Cell Mol Life Sci 74: 827-835. [Crossref]

78. Raasakka A, Ruskamo S, Kowal J, Han H, Baumann A, et al. (2019) Stahlberg H Molecular structure and function of myelin protein P0 in membrane stacking. Sci Rep 9: 642

79. Pasquali R, Anconetani B, Chattat R, Biscotti M, Spinucci G, et al. (1996) Hypothalamicpituitary-adrenal axis activity and its relationship to the autonomic nervous system in women with visceral and subcutaneous obesity: effects of the corticotropin-releasing factor/arginine-vasopressin test and of stress. Metabolism 45: 351-356.

80. Weissenbach J, Friedman JM (1995) The human obese (OB) gene: RNA expression pattern and mapping on the physical, cytogenetic, and genetic maps of chromosome 7 Genome Res 5: 5-12.

81. Couce ME, Burguera B, Parisi JE, Jensen MD, Lloyd RV (1997) Localization of leptin receptor in the human brain. Neuroendocrinology 66: 145-150. [Crossref]

82. Hegyi K, Fülöp K, Kovács K, Tóth S, Falus A (2004) Leptin induced signal transduction pathways. Cell Biol Int 28: 159-169.

83. Takeda Y, Murakami Y, Asou H, Uyemura K (2001) The roles of cell adhesion molecules on the formation of peripheral myelin. Keio J Med 50: 240-248. [Crossref]

84. Kidd G, Trapp BD (2010) Molecular organization of the oligodendrocyte and myelin In: Armati PJ, Mathey EK, eds. The Biology of Oligodendrocytes. Cambridge: Cambridge University Press pp: 64-102.

85. Simons K, Ikonen E (1997) Functional rafts in cell membranes. Nature 387: 569-572. [Crossref]

86. García-Arribas AB, Alonso A, Goñi FM (2016) Cholesterol interactions with ceramide and sphingomyelin. Chem Phys Lipids 199: 26-34.

87. Robertson JD (1958) Structural alterations in nerve fibers produced by hypotonic and hypertonic solutions. J biophys biochem Cytol 4: 349-364.

88. Rayleigh JWS (1883) Investigation of the character of the equilibrium of an incompressible heavy fluid of variable density. Proc Lond Math Soc 14: 170-177.

89. Taylor GI (1950) The instability of liquid surfaces when accelerated in a direction perpendicular to their planes. Proc Roy Soc Lond Series A, Math Phys Sci 201: 192-196.

Copyright: $\odot 2019$ Gilloteaux J. This is an open-access article distributed under the terms of the Creative Commons Attribution License, which permits unrestricted use, distribution, and reproduction in any medium, provided the original author and source are credited. 